Review Article

www.ijrap.net

\title{
MODERN CONCEPT OF STORAGE AND PACKAGING OF RAW HERBS USED IN AYURVEDA
}

Sameet Masand $^{1 *}$, Swati Madan 2 , S.K. Balian ${ }^{3}$

${ }^{1}$ Research Scholar, Department of Rasa Shastra and Bhaishajya Kalpana, R.G.G.P.G. Ayurveda College, Paprola, India

${ }^{2}$ Assistant Professor, Department of Pharmacognosy, Amity Institute of Pharmacy Noida, India

${ }^{3}$ Former Reader, Department of Rasa Shastra and Bhaishajya Kalpana, R.G. Government P. G. Ayurvedic College,

Paprola, Senior Ayurveda Expert TKDL, Member Ayurveda Pharmacopeia Committee, Department of AYUSH, Govt. of India, Former Manager, Government Ayurvedic Pharmacy, Jogindernagar, Himachal Pradesh, India

Received on: 04/02/14 Revised on: 23/03/14 Accepted on: 02/04/14

\section{*Corresponding author}

Dr. Sameet Masand MD (Ayu), Research Scholar, Department of Rasa Shastra and Bhaishajya Kalpana, R.G.G.P.G. Ayurveda College, Paprola, India E-mail: sameetmasand2373@gmail.com

DOI: $10.7897 / 2277-4343.05249$

\section{ABSTRACT}

Herbal medicines are referred as Herbalism or Botanical Medicine or Phytomedicines. With the increasing use of Herbal Medicines, its marketing and safety has become a major concern for health authorities. The WHO estimates that 4 billion people about $80 \%$ of world population use Herbal Medicines for some kind of primary healthcare The WHO developed a strategy on traditional medicines for the period 2002-2005. One of the major objectives was to promote safety, efficacy and quality of Traditional Medicine. The safety and efficacy of Ayurvedic herbal medicine can be achieved by proper Storage and Handling of herbs for various Ayurvedic Dosage Forms. The storage and handling of raw Ayurvedic Herbal drugs can be improved by emphasizing on good storage house for storage of herbs, packaging of raw herbs, testing of raw herbs as per API format, removal of microbes from raw herbs, processes of sterilization and tips for good storage of herbs etc. The assessment of quality, safety and efficacy of medicinal plants can be established and improved by regulating the storage, packaging and handling of raw herbs for various Ayurvedic herbal drugs which is the most important aspect in this direction. The standardization of storage, packaging and handling of raw herbal drug results in highly safe, effective and quality herbal products which would accelerate the global acceptance of Indian system of Medicine.

Keywords: Herbal medicines, WHO, Ayurvedic Dosage Forms

\section{INTRODUCTION}

Herbal medicine is the oldest form of health care known to the mankind. For this reason, Herbal Medicine has been used therapeutically all around the world, being an important aspect of various traditional medicine system ${ }^{1}$. WHO notes that of 119 plants derived pharmaceutical medicines, about $74 \%$ are used in modern medicine for the same medicinal value which has been used as in traditional system of medicine ${ }^{2}$. Presently $90 \%$ of the world population still relies completely on raw herbs and unrefined extracts as medicines ${ }^{2}$. There is a major question regarding the safety, efficacy and quality of herbal drugs. WH has taken steps in assessment of quality, safety and efficacy of medicinal plants thus the storage, packaging and handling of herbs for various Ayurvedic Dosage Forms is an important aspect. As the plant material varies in its percentage of alkaloids (Active principle) therefore its therapeutic efficacy also varies according to the different places of collection, different time of collection, environmental factors, surrounding of the cultivation of a particular medicinal plant $^{3}$. Vegetable drugs used as such or in formulation, should be duly identified and authenticated and be free from insects, pests, fungi, micro-organism, pesticide and other animal matter including animal excreta. These may be within the permitted and specified limit for lead, arsenic and heavy metals and show no abnormal odor, color, sliminess, mould or other evidence of deterioration. The quantitative tests e.g. total ash, acid insoluble ash, water-soluble ash, alcohol-soluble extractive; water-soluble extractive, ether-soluble extractive, moisture content; volatile oil content and assay are the methods which are the essential parts for standards as per Ayurvedic Pharmacopoeia of India 4 . Safety and efficacy also depends upon storage, packaging and handling of raw material, quality control during the process of production of herbal medicine, and their self life time, preservative used and pesticide residue etc. For all these reasons, it is evident that the raw herbal drugs requires a series of extended studies aimed at establishing the safety and efficacy of raw herbal drugs by changing or improving the methods of storage and handling of raw herbs used in Ayurveda. Exposure to light, oxygen and microbes have direct effect on the shelf life of the herbs. Air oxidizes the raw herbs whereas light decomposes the herbs as a result of which stability is reduced. Raw herbs need to be carefully studied to select suitable packaging material so that products are compatible with the material and retain properties. Raw herbal drugs may be stored under conditions that prevent contamination and deterioration. Precaution should be taken in relation to the effects of atmosphere, moisture, heat and light may be taken into consideration so that the active constituent of raw herbs remains stable for a longer period of time. Changes in color, odor and taste physical structure are the indications for the deterioration of medicinal constituents of the herbs. Contamination and deterioration can be prevented by proper storage methods which ensure the safety and efficacy of finished herbal products. Before the storage of raw herbs, these may be cleaned, washed in order to remove earthy material and other contaminants, sterilized to prevent contamination and dried properly. Furthermore, identity, purity, strength, limits of heavy metals, microbial load, pesticide residue, aflatoxins may also be assessed as per 
the standards according to Ayurvedic Pharmacopeia of India.

Good store house for storage of herbs

There shall be adequate space in the store house for 'Under test;' Approved and 'Rejected' herbs with arrangements and equipments to allow washing cleaning, drying and orderly placement of stored herbs with controlled temperature and humidity. The store house for storage of herbs, handling of herbs and drying space etc. shall be as per the provision of GMP.

Stores under GMP 1.1(F) - proper ventilation, free from dampness, adequate space for different type of material.

Stores under GMP 1.1(F)(A)- different stores may be used for herbs as mentioned below

- Fresh herbs

- Dry herbs

- Plant concentrates/ extracts
Steps involved for proper storage of raw herbs

- Identification by naked eyes

- Cleansing of herbs-

Flowers, fruits etc may be cleaned.

- Washing of crude drugs-

Washing of crude drug like stem barks, roots, leaves, stems may be done with potable water.

- Drying of crude raw herbs

- Removal of microbes from raw herbs

Generally the limits for bacterial and mould contamination for internal use shall be considered as same as for food stuffs. Considerable quantities of drugs are sterilized by special equipments by treatment with ethylene oxide. Sterilization is the process in which there is complete destruction of all bacterial life including their spores but in disinfection, there is destruction of bacteria but not their spores. A product is said to be sterile when it is free from all living micro-organisms and passes the sterility test.

Table 1: Permissible limits of microbial load and pathogens

\begin{tabular}{|c|c|c|c|c|}
\hline S. No. & Microbial load & \multicolumn{3}{|c|}{ Permissible limit as per WHO/API } \\
\cline { 3 - 5 } & & $\begin{array}{c}\text { For contamination in the } \\
\text { crude plant materials }\end{array}$ & $\begin{array}{c}\text { For plant materials that have been } \\
\text { pretreated (used as topical doses form) }\end{array}$ & $\begin{array}{c}\text { For other plant materials } \\
\text { for internal use }\end{array}$ \\
\hline 1. & Total viable aerobic count & & $10^{7} \mathrm{cfug}^{-1}$ & $<10^{5} \mathrm{cfug}^{-1}$ \\
\hline 2. & E. coli & $10^{4} \mathrm{~g}^{-1}$ & $10^{2} \mathrm{~g}^{-1}$ & $10 \mathrm{~g}^{-1}$ \\
\hline 3. & Total yeast and mould count & $10^{5} \mathrm{~g}-1$ & $10^{4} \mathrm{~g}^{-1}$ & $10^{3} \mathrm{~g}^{-1}$ \\
\hline 4. & Total enterobacteriaceae & - & $10^{4} \mathrm{~g}^{-1}$ & $10^{3} \mathrm{~g}^{-1}$ \\
\hline 5. & Salmonellae spp. & None & None \\
\hline 6. & S. aureus & Absent & Absent & Absent \\
\hline 7. & Pseudomonas aeruginosa & Absent & Absent & Absent \\
\hline 8. & Coliforms & Absent & & \\
\hline
\end{tabular}

\section{Sterilization of raw herbs}

Sterilization of raw herbs which needs to be stored may be done by any of the below mentioned methods as applicable

- Dry heat sterilization,

- Steam sterilization,

- Sterilization by radiation like infra-red radiation, UV rays, X-rays and Gama rays, Alpha radiations and Beta radiation.

- Chemical method-Gaseous sterilization like ethylene oxide.

\section{Temperature for storage of Raw Herbal Drugs}

All the raw herbal drugs may be stored at a cool place (any temperature) between $8^{0}-25^{0}$, raw herbs must be protected from moisture, freezing, light and excessive heat for preventing decomposition.

Testing of quality raw herbs

Testing of raw herbs may be conducted as per the guidelines of WHO

- Authentication - Taxonomical study and Botanical identity may be established.

- Foreign matter - Herbs should be entirely free from soil, stones, dust, insects and other animal contamination.
- Organoleptic evaluation- It include the macroscopic appearance of drug, its odor, taste, sound, feel of touch, color.

- Microscopic examination - It gives information regarding type of stomata, vessel thickenings which is helpful for identification of species.

- Volatile matter - Volatile oil in Mentha, Ocimum etc. is determined by steam distillation of plant. It plays an important role for quality control parameter.

- Ash value - The presence of ash in medicinal plant is determined as Total Ash, Acid Insoluble Ash etc. A high acid insoluble as indicates contamination with earthy material.

- Extractive values - It also indicates regarding quality of raw herb.

- Chromatographic profile and Marker component Thin layer chromatography and High performance liquid chromatography (HPTLC) provides information regarding the active alkaloids of drug.

- Pharmacological evaluation- Bitterness value, Hemolytic activity, Foaming index etc.

- Toxicological pesticides residues - Pesticides are helpful to reduce the presence of insects, fungi and moulds in raw herbs. Medicinal plants are to be taken for longer period so pesticides residue limit may be established for safety. 
- Microbial contamination - The presence of microbes, moulds, aflatoxins in plant material may be tested.
- Radioactive contamination - The presence of radioactive particles may also be tested.

- Determination of heavy metals -In plants material show permissible limit by WHO

Table 2: Permissible limit of Heavy metal

\begin{tabular}{|c|c|c|}
\hline Heavy metal & $\begin{array}{c}\text { National sanitation foundation draft } \\
\text { proposal (Raw Dietary Supplement) }\end{array}$ & $\begin{array}{c}\text { National sanitation foundation draft proposal (Finished } \\
\text { Dietary Supplement) }^{\mathbf{6}^{-}}\end{array}$ \\
\hline Mercury & - & $0.02 \mathrm{mg} / \mathrm{day}$ \\
\hline Cadmium & $0.3 \mathrm{ppm}$ & $0.006 \mathrm{mg} / \mathrm{day}$ \\
\hline Lead & $10 \mathrm{ppm}$ & $0.02 \mathrm{mg} / \mathrm{day}$ \\
\hline Arsenic & $5 \mathrm{ppm}$ & $0.01 \mathrm{mg} / \mathrm{day}$ \\
\hline Chromium & $2 \mathrm{ppm}$ & $0.02 \mathrm{mg} / \mathrm{day}$ \\
\hline
\end{tabular}

Table 3: Permissible limit heavy metal cosmetic herbal products (Herbal Cosmetic Health Canada)

\begin{tabular}{|c|c|}
\hline Heavy metal & Permissible Limit \\
\hline Mercury & $1 \mathrm{ppm}$ \\
\hline Cadmium & $0.30 \mathrm{ppm}$ \\
\hline Lead & $10 \mathrm{ppm}$ \\
\hline Arsenic & $3 \mathrm{ppm}$ \\
\hline
\end{tabular}

ppm - Parts Per Million

Testing of raw herbs as per API

Testing of raw herbs may be conducted for Macroscopic examination, Microscopic examination identity, purity and strength, TLC, constituents etc. Determination of heavy metals:-In plants material permissible limit by API

Table 4: Permissible limit as per API

\begin{tabular}{|c|c|}
\hline Heavy metal & Permissible limit $^{\mathbf{8}}$ \\
\hline Mercury & $1 \mathrm{ppm}$ \\
\hline Cadmium & $0.3 \mathrm{ppm}$ \\
\hline Lead & $10 \mathrm{ppm}$ \\
\hline Arsenic & $3 \mathrm{ppm}$ \\
\hline \multicolumn{2}{|c|}{ ppm - Parts Per Million } \\
\hline
\end{tabular}

Table 5: Test parameters for raw plant material as CCRAS

\begin{tabular}{|c|c|}
\hline $\begin{array}{l}\text { S. } \\
\text { No. }\end{array}$ & Test parameters ${ }^{5}$ \\
\hline 1. & $\begin{array}{l}\text { Passport data of plant material (place and date of collection), } \\
\text { part of plant, botanical description and adulteration (if any) } \\
\text { reported in literature, substitution (if any) reported in literature. }\end{array}$ \\
\hline 2. & Foreign matter (not more than 2 percent) \\
\hline 3. & Organoleptic character (color, odor, taste and texture etc.) \\
\hline 4. & Macroscopic and microscopic characters, powder microscopy \\
\hline 5. & Loss on drying at $105^{\circ} \mathrm{C} /$ moisture content \\
\hline 6. & $\mathrm{pH}$ value $(10 \%$ aqueous extract $)$ \\
\hline 7. & Total ash \\
\hline 8. & Acid- insoluble ash \\
\hline 9. & Water-soluble extractives \\
\hline 10. & Alcohol- soluble extractives \\
\hline 11. & $\begin{array}{l}\text { Volatile oil percentage (for oil percentage bearing plants, } \\
\text { generally plants belonging to compositae and labiatae family) }\end{array}$ \\
\hline 12. & TLC/HPTLC/GC/HPLC/LC-MS (as per requirement) \\
\hline 13 & $\begin{array}{l}\text { Assay for active constituents (total tannins/ total alkaloids/ } \\
\text { resin etc. or individual constituents) }\end{array}$ \\
\hline 14. & Test for heavy/toxic metals, lead, cadmium, mercury, arsenic \\
\hline 15. & $\begin{array}{c}\text { Pesticide residue, organo chlorine pesticides, } \\
\text { organophosphorus pesticides, pyrethroids }\end{array}$ \\
\hline 16. & $\begin{array}{c}\text { Microbial contamination, total viable aerobic count, } \\
\text { enterobacteriaceae, total fungal count }\end{array}$ \\
\hline 17. & $\begin{array}{l}\text { Test for specific pathogen, Escherichia coli, Salmonella spp., } \\
\text { Staphyloccocus aureus, Pseudomonas aeruginosa }\end{array}$ \\
\hline 18 & Aflatoxins $\left(\mathrm{B}_{1}, \mathrm{~B}_{2}, \mathrm{G}_{1}, \mathrm{G}_{2}\right)$ \\
\hline 19. & Shelf life \\
\hline
\end{tabular}

Table 6: Material for specific packaging and storage of Raw Herbs

\begin{tabular}{|c|c|c|}
\hline $\begin{array}{c}\text { Sr. } \\
\text { No. }\end{array}$ & Category & Packing material \\
\hline 1. & $\begin{array}{c}\text { Woody in nature like } \\
\text { stem, heartwood, } \\
\text { bark etc. }\end{array}$ & Gunny bags and woven sacks \\
\hline 2. & $\begin{array}{c}\text { Soft in nature like } \\
\text { creepers, leaves etc. }\end{array}$ & $\begin{array}{c}\text { High gauge HMHD bags, woven } \\
\text { sacks with LD liner, High gauge } \\
\text { polyethylene bags }\end{array}$ \\
\hline 3. & $\begin{array}{c}\text { Fleshy in nature like } \\
\text { fruits, rhizomes etc. }\end{array}$ & $\begin{array}{c}\text { High gauge HMHD bags, woven } \\
\text { sacks with LD liner, wooden boxes. }\end{array}$ \\
\hline 4. & $\begin{array}{c}\text { Flowers, anthers, } \\
\text { stigma, petals, seeds } \\
\text { etc. }\end{array}$ & $\begin{array}{c}\text { Corrugated box with polypropylene } \\
\text { woven sacks, HDPE containers, Fiber } \\
\text { board's drums }\end{array}$ \\
\hline 5. & $\begin{array}{c}\text { Volatile contents } \\
\text { Air tight HDPE containers, Air tight } \\
\text { HDPE carboys, Card board box with } \\
\text { polyethylene liners }\end{array}$ \\
\hline 6. & $\begin{array}{c}\text { Herbal extracts and } \\
\text { compounds }\end{array}$ & $\begin{array}{c}\text { Air tight HDPE containers, } \\
\text { corrugated box with polyethylene } \\
\text { woven sacks and fiber board's drums } \\
\text { with polyethylene bags. }\end{array}$ \\
\hline
\end{tabular}

HDHM (High molecular weight high density polyethylene), LD liner (Low density liner bags), HDPE (High density polyethylene)

There are no guidelines for proper storage of raw herbal material till date. It is only the proper handling, packaging and storage of herbs which can preserve the safety, efficacy and quality of herbs. Exposures to air, moisture, light, dust etc. all are harmful which should be restricted to maximum extent.

- Dry space and free from dampness or humidity.

- No entry of rodents, birds, insects etc.

- Separate store for different categories of medicinal and aromatic plants e.g. fresh herbs, dry herbs, extracts/gums, volatile oils, poisonous drugs as defined under drug and cosmetic act 1940 schedule.

- Allow free movement of men, machine and equipment.

- Separate sections for 'Under test' 'Approved' and 'Rejected' lots.

- Do not store physically similar looking herbs in the vicinity; it may lead to wrong identity.

- Each lot of herbs stored should bear a label with following details.

$>$ Name of drug

$>$ Name of supplier

$>$ Part (root, stem, bark, leaf, flower, rhizome etc)

$>$ Inspection status (tested/rejected/approved)

$>$ Date of arrival and consignment number

$>$ Test report number and date

$>$ Time of collection 
Best use before date

$>$ Batch no.

$>$ Geographical region of collection.

- Keep authenticated samples as 'references standards' for each drug in store.

- Use herbs on FIFO (First In First out).

- Keep containers of herbs on wooden or plastic pallets. Keep one herb in one pallet.

- Suitable packaging material is required to store the drugs.

\section{Always Avoid}

- Storing in open spaces, surface directly and alike drug in close vicinity.

- Using inappropriate packaging material.

- Mixing of under tested approved and rejected lots.

- Ignoring FIFO (First In First Out).

- Storing the material for long period.

- Keeping the material within abnormal heat and moisture.

\section{CONCLUSION}

Quality raw herbs may be stored under controlled temperature, pressure, air and light etc in order to retain the active constituents of the herbs in different stores with proper labeling as per the provision of Drug and Cosmetic
Act 1940 after packaging with specific packing material for different parts of the medicinal herbs. In this way, safety, efficacy and quality of the Ayurvedic medicines shall be maintained and would capitalize billions of dollars from emerging herbal markets for our country.

\section{REFERENCES}

1. W.H.O. guidelines for assessing quality of Herbal Medicines with reference to contaminants and residues; 2007. p. 7, 9. W.H.O. Traditional Medicine Strategy; 2002-2005.

2. Introduction to Medicinal plants www.agr.gc.ca. Medicinal plants from ancient times to the present $14^{\text {th }}$ line.

3. Review article RJPT Research J Pharma and tech 2008; 1(4) Standardization Strategies for Herbal Drugs. Neeli Rose Ekka, Kamta Prasad Namdeo Introduction $9^{\text {th }}$ line

4. A.P.I. Part 2 Vol. 4 (Formulations) p. 11

5. Laboratory Guide for the Analysis of Ayurveda and Siddha formulations by CCRAS; 2010. (Annexure-I pg.152, Annexure-2, p. 152, Annexure-3 p. 153, Annexure-3, p. 153, Annexure-4 p.153), (refer table 21, p. 134)

6. W.H.O. guidelines for assessing quality of Herbal Medicines with reference to contaminants and residues. Annexure 3; 2007. p. 24.

7. Health Canada, Draft guidance on heavy metal impurities in cosmetics, Section 4

8. A.P.I. Part 2 Vol 3 (Formulations) p. 149

9. A.P.I. Part 2 Vol. 3 (Formulations) p. 149.

Cite this article as:

Sameet Masand, Swati Madan, S.K. Balian. Modern concept of storage and packaging of raw herbs used in Ayurveda. Int. J. Res. Ayurveda Pharm. 2014;5(2):242-245 http://dx.doi.org/10.7897/2277-4343.05249 